\title{
GROWTH, SOME PHYSIOLOGICAL TRAITS AND PRODUCTIVITY OF SUGAR BEET UNDER DIFFERENT IRRIGATION LEVELS AND MULCH TYPES IN NEW RECLAIMED AREA
}

(Received: 3.10.2019)

\author{
By \\ M.S. El-Kady, Eman M. Abdel Fatah and E.H.S. El-Laboudy \\ Sugar Crops Research Institute, Agricultural Research Center, Giza, Egypt.
}

\begin{abstract}
This work was investigated to study the combined effects of water stress levels [60\%, $80 \%$, and $100 \%$ of irrigation water requirements (IWR)] and different types of soil mulching [non-mulch, organic mulch (paddy straw and sawdust), inorganic mulch (black polyethylene film mulch (BPFM)] under drip irrigation system on growth, some physiological characteristics, yields and quality of sugar beet crop. The study was conducted at a private farm in the vicinity of Cairo-Alexandria Desert Road, Egypt $\left(30^{\circ} 14^{\prime} 14.59^{\prime \prime} \mathrm{N}\right.$ latitude and $30^{\circ} 46^{\prime}$ 53.90" E longitude) during 2017/2018 and 2018/2019 seasons. The experimental design used was a split plot in a randomized complete blocks arrangement with three replications. The results revealed that most of growth, physiological and yield characteristics significantly increased by increasing irrigation levels from $60 \%$ up to 80 or $100 \%$ of irrigation water requirements (IWR) in both seasons. On the contrary, quality parameter of sugar beet decreased by increasing irrigation levels from $60 \%$ to $100 \%$ of IWR. Covering soil with inorganic mulch (black polyethylene film mulch (BPFM)) was significantly more efficient for the growth, physiological and yield parameters followed by organic cover (paddy straw and sawdust) compared to non-mulching in both seasons. The distribution of stomata density of the leaf increased as water stress level increased. There were slight differences between full the irrigation (100\%) and moderate stress (80\% of IWR) for stomata closure \% but stomata closed under severe stress (60\% of IWR). The results also showed that, all mulching types under the three water stress levels had positive effects and increased stomata area, but stomata density and its index as well as stomata closure\% decreased compared with non-mulch. Finally, the highest sugar yield (ton $\mathrm{fed}^{-1}$ ) was observed under moderate stress ( $80 \%$ of IWR) and covering soil by BPFM.
\end{abstract}

Key words: Sugar beet, mulch materials, deficit irrigation, growth, physiological traits, stomata.

\section{INTRODUCTION}

A great intension must be paid to improve water management in farming systems. In line with sustainable agriculture, it has become mandatory apply to the appropriate methods to conserve water required for crop production in the field, especially in newly reclaimed areas. Drought is the major cause of yield and economic losses for the sugar beet crop. The National Water Resources Plan in Egypt estimates that the total cultivated areas would increase to 4.830 .000 ha by 2030 . The current water shortage in Egypt is 13.5 billion cubic meter per year (BCM/yr) and is expected to continuously increase, to reach $26 \mathrm{BCM} / \mathrm{yr}$ in 2025 in the case of continuation of current policies (AQUASTAT, FAO 2016). Water management efficiency is a key issue for sustainable agriculture development, since it is necessary to get a higher biomass.

In Egypt, limited water and agricultural land in addition to climate change, predictions of increase in temperature and decrease in rainfall are problematic in recent years. Therefore, there is a need for a strategy that depends on modern methods and new techniques of irrigation to save water. 
Insufficient water availability is the major cause for sugar beet (Beta vulgaris L.) yield loss worldwide and causes greater yield loss to crops than any other single biotic or abiotic factor (Pidgeon et al. 2006). Insufficient water inhibits the photosynthesis of plants, and thus reduces growth and development (Gong et al. 2005). It also causes the decrease of leaf turgor potential and transpiration rate (Özenç, 2008). Many cellular functions of plants, such as nitrogen metabolism, enzyme activities, protein synthesis and cell membrane function can also be impaired under drought stress (Saneoka et al., 2004). Masri et al. (2015) revealed that drip irrigated sugar beet plants with $75 \%$ of irrigation water requirements (IWR) recorded the highest significant leaf area index, sucrose \%, purity $\%$, extractable sugar\% and white sugar yield. Malik (2017) indicated that irrigation regimes [full irrigation, $20 \%, 40 \%$ and $60 \%$ of $\mathrm{FI}]$ significantly affected all the yield components and water use efficiency of sugar beet. Amr et al. (2017) revealed that drip irrigation system with $1322 \mathrm{~m}^{3}$ water /fed (60\% of IWR) gave the best yield and good quality of sugar beet crop.

Mulching is a practice of covering the soil surface with plastics, organic and non organic materials to reduce evaporation, conserves soil moisture and improves irrigation efficiency. Drip irrigation in combination with mulch is one of the best irrigation methods and cultural practice which can be used to reduce water requirements (Jalota and Prihar, 1998). The negative impacts of water stress may be minimized by employing mulching with suitable materials (Kader et al., 2017). The organic mulching materials, such as straw, sawdust and dry grass, have been used to retain soil moisture by reducing soil-water consumption/loss, stimulate microbial activity, enhance oxygen availability to roots, moderate soil temperature; increase nutrient availability (Zribi et al., 2015), reduce fertilizer leaching, control weeds and increase plant growth, yield and quality (Arora et al., 2011). Artyszak et al. (2014) reported that different types of straw mulches increased root and sugar yields of sugar beet compared to no-mulch treatment. Malik et al. (2018) concluded that application of surface mulches enhanced water use efficiency of sugar beet and produced 11.96 to $19.45 \%$ higher root yield, than No-Mulch treatment.

Therefore, the present study was conducted to determine the optimum and efficient amount of irrigation water application, and suitable mulching types which will improve growth, yield and quality of sugar beet.

\section{MATERIALS AND METHODS}

The experimental work was performed at a private farm behind Cairo-Alexandria Desert Road, Egypt (30 $10^{\circ} 14.59^{\prime \prime} \mathrm{N}$ latitude and $30^{\circ} 46^{\prime} 53.90^{\prime \prime} \mathrm{E}$ longitude) during 2017/2018 and 2018/2019 seasons under drip irrigation system. A split plot design in randomized complete blocks arrangement with three replications was used to evaluate the effect of three water stress levels [60\% (severe stress), $80 \%$ (moderate stress) and $100 \%$ (well water) of irrigation water requirement (IWR)] and their combinations with four mulch types viz., (control) without mulch, two organic mulches (paddy straw and Sawdust, $10 \mathrm{~cm}$ thickens) and inorganic mulch, (black polyethylene film mulch (BPFM), with 50 microns thickens). Main plots were devoted to water regime treatments, while sub plots were randomly occupied by mulching types. The experimental units area was $12 \mathrm{~m}^{2}(5$ ridges, $4 \mathrm{~m}$ long and $60 \mathrm{~cm}$ apart). Sugar beet was sown on ridges $60 \mathrm{~cm}$ apart and 20 $\mathrm{cm}$ between hills. Sugar beet multi-germ variety Faten was sown at the first week of October in both seasons. Nitrogen was added in the form of ammonium nitrates $(33.5 \% \mathrm{~N})$ at a rate of $120 \mathrm{~kg} \mathrm{~N} / \mathrm{fed}$ in five equal splits doses. The first was applied after thinning at 4-leaf stage and other splits were added at two weeks intervals after the first doses. Phosphorous in the form of calcium super phosphate $\left(15.5 \% \quad \mathrm{P}_{2} \mathrm{O}_{5}\right)$ at the rate of $200 \mathrm{~kg} / \mathrm{fed}$ and compost (5 tons /fed) was added during land preparation. Potassium in the form of potassium sulfate $\left(48 \% \mathrm{~K}_{2} \mathrm{O}\right)$ was added at the rate of $48 \mathrm{~kg}$ /fed with the last does of nitrogen fertilizer. Organic mulching was done before planting. Plastic mulch was carefully spread over the plots and holes were punched, where seedlings were to be established.Other culture practices were done according to the 
Sugar Crops Research Institute (SCRI) recommendation. Soil (0-20, 20-40 and 40$60 \mathrm{~cm} \mathrm{depth)}$ and water samples were collected from the experimental site to determine its physical and chemical properties using the methods described by Cottenie et al. (1982) as shown in Tables (1 and 2). water applied $\left(\mathrm{m}^{3} / \mathrm{fed}\right)$ throughout the growing seasons for the three studied water stress treatments under drip irrigation systems.

\subsection{Studied characters}

\subsubsection{Growth traits}

Three samples were taken at 105, 135 and 165 days after planting (DAP), each

Table (1): Physical and chemical properties of the soil samples of the experimental site (average of two seasons).

\begin{tabular}{|c|c|c|c|c|c|c|c|c|c|c|c|}
\hline \multirow{2}{*}{$\begin{array}{l}\text { Soil layer } \\
\quad(\mathrm{cm})\end{array}$} & \multicolumn{3}{|c|}{$\begin{array}{c}\text { Particle size } \\
\text { distribution \% }\end{array}$} & \multirow{2}{*}{\multicolumn{4}{|c|}{ Texture class }} & \multicolumn{4}{|c|}{ Moisture content (\%) } \\
\hline & Sand & Silt & Clay & & & & & F.C & W.I & & A.W \\
\hline $0-20$ & 91.5 & 6.5 & 2.0 & \multirow{3}{*}{\multicolumn{4}{|c|}{ Sandy }} & 14.8 & 5. & & 8.7 \\
\hline $20-40$ & 94.0 & 4.3 & 1.7 & & & & & 15.2 & 6.2 & & 9.5 \\
\hline $40-60$ & 95.2 & 3.5 & 1.3 & & & & & 15.5 & 5.9 & & 10.1 \\
\hline \multirow{2}{*}{$\begin{array}{l}\text { Soil layer } \\
(\mathrm{cm})\end{array}$} & \multirow{2}{*}{ SAR } & \multirow{2}{*}{$\mathrm{PH}$} & \multirow{2}{*}{$\begin{array}{c}\mathrm{EC} \\
(\mathrm{dS} / \mathrm{m})\end{array}$} & \multicolumn{4}{|c|}{$\begin{array}{l}\text { Soluble anions } \\
(\mathrm{meq} / \mathrm{l})\end{array}$} & \multicolumn{4}{|c|}{$\begin{array}{l}\text { Soluble cations } \\
(\mathrm{meq} / \mathrm{l})\end{array}$} \\
\hline & & & & $\mathrm{CO}_{3}^{--}$ & $\mathrm{HCO}_{3}$ & $\mathrm{Cl}^{-}$ & $\mathrm{SO}_{4}^{--}$ & $\mathrm{Ca}^{++}$ & $\mathrm{Mg}^{++}$ & $\mathrm{Na}^{+}$ & $\mathrm{K}^{+}$ \\
\hline $0-20$ & 0.95 & 7.90 & 0.50 & 0.1 & 0.50 & 3.50 & 0.98 & 1.60 & 0.50 & 2.85 & 0.13 \\
\hline $20-40$ & 1.23 & 8.10 & 0.32 & 0.1 & 0.50 & 2.00 & 0.68 & 1.10 & 0.50 & 1.60 & 0.08 \\
\hline $40-60$ & 1.52 & 8.00 & 1.60 & 0.1 & 1.00 & 10.5 & 4.48 & 4.53 & 2.51 & 8.72 & 0.32 \\
\hline
\end{tabular}

Table (2): Chemical analysis of irrigation water

\begin{tabular}{|c|c|c|c|c|c|c|c|c|c|c|}
\hline \multirow{2}{*}{$\mathrm{PH}$} & \multirow{2}{*}{$\begin{array}{c}\mathrm{EC} \\
\end{array}$} & \multicolumn{4}{|c|}{ Soluble anions (meq/l) } & \multicolumn{4}{|c|}{ Soluble cations (meq/l) } & \multirow{2}{*}{ SAR } \\
\cline { 3 - 11 } & $\mathrm{CO}_{3}^{--}$ & $\mathrm{HCO}_{3}^{-}$ & $\mathrm{Cl}^{-}$ & $\mathrm{SO}_{4}^{--}$ & $\mathrm{Ca}^{++}$ & $\mathrm{Mg}^{++}$ & $\mathrm{Na}^{+}$ & $\mathrm{K}^{+}$ & \\
\hline 7.30 & 5.00 & 0.1 & 2.4 & 48 & 16.13 & 22.8 & 16.2 & 26.8 & 0.73 & 6.06 \\
\hline
\end{tabular}

2.1.Calculation of irrigation water requirements

Irrigation water requirements were determined using Blaney and Criddle (1962) method:

$$
\mathrm{IR}_{\mathrm{c}}=\frac{\left[\left(\mathrm{ET}_{\mathrm{o}} \times \mathrm{K}_{\mathrm{c}}\right) \times \mathrm{Dd}\right]}{\mathrm{Es}}
$$

Where: $\mathrm{IR}_{\mathrm{c}}=$ total actual irrigation water requirements $(\mathrm{mm} /$ intervals $), \quad \mathrm{ET}_{\mathrm{o}}=$ evapotranspiration $(\mathrm{mm} /$ day) was calculated according to CROPWAT program (Smith, 1991), $K_{c}=$ crop coefficient (Doorenbos and Kassam, 1979), $\mathrm{D}_{\mathrm{d}}=$ time intervals and $\mathrm{E}_{\mathrm{s}}=$ system efficiency (\%).

Metrological data of the experimental site according to Chapman and Praft (1961) at Southern Tahrir region are illustrated in Table (3). Values of crop factor $\left(\mathrm{K}_{\mathrm{c}}\right)$ through the growing seasons are shown in Table (4). Table (5) exhibits the average amounts of sample (five guarded plans) was separated into foliages and roots to determine total dray weight $(\mathrm{g} / \mathrm{plant})$ and leaf area $\left(\mathrm{cm}^{2}\right)$. For leaf area measurement, the disk method was followed according to Watson (1958). The following growth parameters were calculated:

1. Leaf area index $($ LAI $)=$ leaf area per plant $\left(\mathrm{cm}^{2}\right) /$ Plant ground area $\left(\mathrm{cm}^{2}\right)$

2. Crop growth rate (CGR) (g. week $\left.{ }^{-1}\right)$.

$\mathrm{CGR}=\left(\mathrm{W}_{2}-\mathrm{W}_{1}\right) /\left(\mathrm{T}_{2}-\mathrm{T}_{1}\right)$

3. Relative growth rate (RGR) (g.g ${ }^{1}$.week ${ }^{-1}$ ) (Watson, 1958).

$\mathrm{RGR}=\left(\ln \mathrm{W}_{2}-\ln \mathrm{W}_{1}\right) /\left(\mathrm{T}_{2}-\mathrm{T}_{1}\right)$

4. Net assimilation rate (NAR) $\left(\mathrm{g} . \mathrm{cm}^{-}\right.$ ${ }^{2}$. $^{2}$ eek $^{-1}$ ) (Radfords, 1967).

$N A R=\left(W_{2}-W_{1}\right)\left(\ln A_{2}-\ln A_{1}\right) /\left(A_{2}-A_{1}\right)\left(T_{2}-T_{1}\right)$. Where: $\mathrm{W}_{1}, \mathrm{~A}_{1}$ and $\mathrm{W}_{2}, \mathrm{~A}_{2}$, refer to dry weight per plant and leaf area at time $T_{1}$ and $\mathrm{T}_{2}$, respectively. 
M.S. El-Kadv et al., ................................................................

Table (3): Average agro-meteorological data of Southern Tahrir region (average of two seasons).

\begin{tabular}{|l|c|c|c|c|c|c|}
\hline \multicolumn{1}{|c|}{ Month } & $\begin{array}{c}\text { Max. } \\
\text { temp } \\
\left(\mathbf{C}^{\circ}\right)\end{array}$ & $\begin{array}{c}\text { Min. } \\
\text { temp } \\
\left(\mathbf{C}^{\mathbf{0}}\right)\end{array}$ & $\begin{array}{c}\text { Relative } \\
\text { humidity } \\
(\mathbf{\%})\end{array}$ & $\begin{array}{c}\text { Wind speed } \\
(\mathbf{k m} / \mathbf{d a y})\end{array}$ & $\begin{array}{c}\text { Sunshine } \\
(\mathbf{h r})\end{array}$ & $\begin{array}{c}\text { Evapotranspiration } \\
\left(\mathbf{E T}^{\circ}\right) \\
(\mathbf{m m})\end{array}$ \\
\hline October & 30.4 & 14.5 & 57 & 8.4 & 8.4 & 4.98 \\
\hline November & 25.4 & 10.4 & 69 & 7.4 & 7.4 & 2.73 \\
\hline December & 21.3 & 6.9 & 69 & 6.2 & 6.2 & 2.14 \\
\hline January & 19.8 & 5.6 & 67 & 6.1 & 6.1 & 2.29 \\
\hline February & 21.2 & 7.3 & 65 & 7.0 & 7.0 & 2.97 \\
\hline March & 23.8 & 10.9 & 63 & 7.8 & 7.8 & 3.71 \\
\hline April & 28.2 & 11.4 & 56 & 8.7 & 8.7 & 5.04 \\
\hline Average/year & 28.2 & 12.6 & 58 & 8.5 & 8.5 & 4.45 \\
\hline
\end{tabular}

Source: Southern Tahrir agro-meteorological station

Table (4): Crop factor $\left(K_{c}\right)$ through the growing season of sugar beet in the semi-arid region (FAO, 1979).

\begin{tabular}{|c|c|c|c|c|c|c|c|c|}
\hline \multicolumn{2}{|c|}{ Initial } & \multicolumn{2}{c|}{ Crop development } & \multicolumn{2}{c|}{ Mid-season } & \multicolumn{2}{c|}{ Late-season } & $\begin{array}{c}\text { Total } \\
\text { (days) }\end{array}$ \\
\cline { 1 - 7 } $\begin{array}{c}\text { Time } \\
\text { (days) }\end{array}$ & $\mathrm{K}_{\mathrm{c}}$ & $\begin{array}{c}\text { Time } \\
(\text { days })\end{array}$ & $\mathrm{K}_{\mathrm{c}}$ & $\begin{array}{c}\text { Time } \\
(\text { days })\end{array}$ & $\mathrm{K}_{\mathrm{c}}$ & $\begin{array}{c}\text { Time } \\
(\text { days })\end{array}$ & $\mathrm{K}_{\mathrm{c}}$ & 210 \\
\hline 30 & 0.35 & 60 & $0.35>\mathrm{K}_{\mathrm{c}}<1.2$ & 60 & 1.2 & 60 & $1.2>\mathrm{K}_{\mathrm{c}}<0.7$ & 210 \\
\hline
\end{tabular}

Table (5): Amounts of applied irrigation water requirements (IWR) ( $\left.\mathrm{m}^{3} / \mathrm{fed}\right)$ throughout growing season.

\begin{tabular}{|c|c|c|c|c|}
\hline \multirow{2}{*}{$\begin{array}{c}\text { Days from } \\
\text { planting }\end{array}$} & \multirow{2}{*}{ Growth stage } & \multicolumn{3}{|c|}{ Amount of water ( $\mathrm{m}^{3} /$ feddan*) } \\
\hline & & $60 \%$ & $\mathbf{8 0 \%}$ & $100 \%$ \\
\hline 1 & \multirow{2}{*}{ Initial } & \multirow{2}{*}{158.3} & \multirow{2}{*}{158.3} & \multirow{2}{*}{158.3} \\
\hline 30 & & & & \\
\hline 31 & \multirow{2}{*}{ Development } & \multirow{2}{*}{260.2} & \multirow{2}{*}{433.7} & \multirow{2}{*}{433.7} \\
\hline 90 & & & & \\
\hline 91 & \multirow{2}{*}{ Mid-season } & \multirow[t]{2}{*}{462.6} & \multirow[t]{2}{*}{616.8} & \multirow{2}{*}{771.0} \\
\hline 150 & & & & \\
\hline $\begin{array}{l}151 \\
210\end{array}$ & Late-season & 709.9 & 946.5 & 1183.1 \\
\hline & e season & 1591.0 & 2155.3 & 2546.1 \\
\hline
\end{tabular}

feddan $($ fed $)=4200 \mathrm{~m}^{2}$

\subsubsection{Biochemical analyses}

After 120 days from planting random samples were taken from each sub plot to determine the following:

1. Photosynthetic pigments (mg/g f.w.) i.e. chlorophyll $\mathrm{a}, \mathrm{b}$ and carotenoides according to Wettstein (1957).

2. Proline content was estimated by the ninhydrin method as cited by Bates et al. (1973).

2.2.3. Leaf relative water content (LRWC \%) was estimated according to the method of Weatherly (1950). Samples (0.5 g) of leaves were saturated in $100 \mathrm{ml}$ distilled water for $24 \mathrm{~h}$ and their turgid weights were recorded. Then, they were oven-dried at $65^{\circ} \mathrm{C}$ for $48 \mathrm{~h}$ and their dry weights were recorded. LRWC was calculated as follows:

$\mathrm{LRWC}(\%)=[(\mathrm{FW}-\mathrm{DW}) /(\mathrm{TW}-\mathrm{DW})] \times 100$

Where: FW, DW and TW are fresh, dry and turgid weights, respectively.

\subsubsection{Quality parameters}

At harvest (210 DAP), a sample of ten roots were taken at random from each sub plot cleaned and sent to the Sugar Beet Laboratory at Nubaria Sugar Factory, ElBeheira Governorate, Egypt, to determine the following: 
1. Sucrose percentage: was estimated by using sacharometer lead acetate extract of fresh macerated roots according to Carruthers and Oldfield (1960).

2. Juice impurities: in terms of Alpha amino nitrogen ( $\alpha$-amino $N$ ), Sodium (Na) and Potassium (K) concentrations according to the procedure of Sugar Company by Auto Analyzer as described by Cooke and Scott (1993), and calculated using the following formula:

Juice impurities $=0.343(\mathrm{~K}+\mathrm{Na})+0.094$

$$
\alpha \text {-amino } \mathrm{N}+0.29 \text {. }
$$

3. Extractable sugar percentage (ES\%) was estimated according to Reinefeld $e t$ al.(1974) by using the following formula:

$\mathrm{ES} \%=\operatorname{pol} \%-[0.343(\mathrm{~K}+\mathrm{Na})+0.094 \alpha-$ amino $\mathrm{N}+0.29]$.

Where: $\mathrm{Pol} \%=$ sucrose percentage

4. Juice purity percentage $=(\mathrm{ES} \% / \mathrm{pol}) \times 100$ 2.2.5. Yields

At harvest, root weight per plot was obtained and used to calculate:

1. Root yield (ton $\mathrm{fed}^{-1}$ ).

2. White sugar yield $\left(\right.$ ton $\left.\mathrm{fed}^{-1}\right)=\operatorname{root}$ yield $\left(\right.$ ton $\left.\mathrm{fed}^{-1}\right) \times($ extractable sugar $\%$ /100).

2.2.6. Leaf stomata measurements: The morphological changes of stomata (stomata density $\left(\right.$ No. $\left.\mathrm{mm}^{2}\right)$, area $(\mu \mathrm{m})$, stomatal closure $\%$ and its index) for abaxial and adaxial surface of fully expanded mature leaves were measured through Transmission Electronic Microscope (TEM) Model JEOL (JEM-1400 TEM, Japan) linked with the software program at TEM lab (FA-CURP), Faculty of Agriculture, Cairo University Research Park. The leaf stomata index (SI) was estimated using the following formula:

$$
\mathrm{SI}=\frac{\text { Number of stomata }}{\text { Number of stomata }+ \text { epidermis cell }} \times 100
$$

\subsection{Statistical analysis}

Collected data were statistically analyzed according to Snedecor and Cochran (1989). Treatment means were compared using least significant difference (LSD) at 5\% level of probability.

\section{RESULTS AND DISCUSSION}

\subsection{Effect of water stress levels}

\subsubsection{Growth traits}

Results in Tables (6) show that, crop growth rate (CGR), net assimilation rate (NAR), relative growth rate (RGR) and leaf area index (LAI) significantly decreased by increasing water deficit from $100 \%$ to $60 \%$ of the irrigation water requirements (IWR) in both seasons, with exception RGR during 135-165 days after planting (DAP). The highest values of CGR $(13.12,12.31 \mathrm{~g} /$ week $)$ and $\left(13.58,12.46 \mathrm{~g} /\right.$ week) in the $1^{s t}$ and $2^{n d}$ seasons were obtained under complete irrigation condition at the two sampling dates, respectively. However, NAR values were the highest $(3.12,2.60$ and 3.13, 2.65 $\mathrm{g} / \mathrm{cm}^{2} /$ week) at the two growth stages under $80 \%$ of irrigation water requirements. Also the pervious treatment gave the highest LAI values (3.83 and 4.55) in the $1^{\text {st }}$ and $2^{\text {nd }}$ seasons, respectively, with insignificant differences were noticed between 100 and $80 \%$ of IWR in the $2^{\text {nd }}$ season. At the beginning of the growing season, CGR, NAR and RGR were in the highest rate in both seasons and then gradually began to decrease. This may be due to the fact at the beginning of the growing season the leaves were fully exposed to light, so their NAR was at maximum. At the end of the growing season, NAR decreased, results in increases in leaf area and the number of leaves per plant of sugar beet and thus increase in shading among them (Balak, 1993). The reduction in CGR, RGR and NAR with increasing water stress levels may be due to the reduction in cell division and expansion, which in turn reduced photosynthetic surface of sugar beet plant, stomata closure to avoid excessive water losses occurs rapidly and is widely recognized as the primary effect of drought on carbon assimilation Chaves et al. (2002). A similar trend was reported by Amr et al. (2017) who mentioned that drip irrigation system with $80 \%$ of (IWR) recorded the highest significant leaf area index of sugar beet. ElSayed et al. (2018) noticed that increasing water stress level from 30 up to $70 \%$ from F.C significantly decreased beet growth. ElKady et al. (2019) found that, significant increases were detected in leaf area index, crop growth rate and net assimilation rate of sugar beet plant during the period between 30 to 90 and 90 to 150 days from planting by increasing IWR from $60 \%$ up to $100 \%$.

3.1.2. Photosynthetic pigments, proline and leaf relative water content

The results shown in Table (7) cleared that the examined water regimes gave significant effect on the values of leaf 
chlorophyll (a and b), carotenoids, proline and leaf relative water content (LRWC) in the two seasons. Full irrigation $(100 \%$ of IWR) overpassed the other two water stress levels under study for leaf chl. a in the $2^{\text {nd }}$ season, carotenoids and LRWC in both seasons. Meanwhile, the highest values of chl. a in the ${ }^{s t}$ season and chl. b in the two seasons resulted from $80 \%$ of IWR with no significant differences were seen among $100 \%$ and $80 \%$ of IWR for chlorophyll a and $\mathrm{b}$ in the $1^{\text {st }}$ season. Water stress levels $80 \%$ and $100 \%$ of IWR caused significant increases amount to (9.07 and 8.29\%) and (6.53 and $7.79 \%$ ) for chl. a, corresponding to (30.34 and 30.90\%) and (29.51 and $25.68 \%)$ for chl. $\mathrm{b}$ and (1.47 and $4.29 \%)$ and (35.38 and $38.14 \%$ ) for carotenoids and finally (8.33 and $10.10 \%)$ and (9.01 and $11.14 \%$ ) for (LRWC) in the $1^{\text {st }}$ and $2^{\text {nd }}$ seasons, respectively, compared to water regime $60 \%$.Concerning the leaf proline concentration (Table 7), proline concentration responded rapidly and strongly to water stress levels and significantly increased by $8.33 \%$ with moderate drought stress (80\% of IWR) and by $24.67 \%$ with severe drought stress $(60 \%$ of IWR) compared to (100\% of IWR) in the $2^{\text {nd }}$ season. While ( $80 \%$ of IWR) recorded the lowest concentration of proline in the $1^{\text {st }}$ season as compared with the other water stress levels. Decreased photosynthetic rates under severe drought stress conditions may be due to lower stomata size (Fig.3 and 4) and reduced intercellular $\mathrm{CO}_{2}$ concentrations as a result of stomatal closure and $\mathrm{CO}_{2}$ diffusion limitations under reduced free water conditions (Chaves et al., 2003). Accumulation of proline is regarded as an adaptive metabolic acclimation of plants to drought stress; proline can act as a free radical scavenger. Similar results were reported by Neseim et al. (2014), who stated that drought stress significantly reduced chlorophyll a and total chlorophyll and significantly increased free amino acids concentrations in leaves of sugar beet plant. Azab (2018) stated that high levels of drought (75 and 50\% field capacity) reduced the amount of chlorophyll a, b and total carotenoids of sugar beet leaves.

\subsubsection{Yield and quality}

As shown in Table (8), decreasing irrigation water quantity from 100 to $60 \%$ of IWR significantly reduced root yield by 2.34 and 4.01 ton fed $^{-1}$ and impurities by 0.99 and $1.36 \%$ in the $1^{s t}$ and $2^{\text {nd }}$ seasons, respectively as well as purity by $3.56 \%$ in the $2^{\text {nd }}$ season. On the other hand, sucrose $\%$ significantly increased by 2.44 and $4.50 \%$ as well as extractable sugar by 3.43 and $5.87 \%$ in the $1^{s t}$ and the $2^{\text {nd }}$ seasons, respectively, and sugar yield by 0.55 ton /fed in the $2^{\text {nd }}$ season. Irrigated sugar beet plant by $80 \%$ of IWR recorded the maximum sugar yield in the $1^{\text {st }}$ season and exhibited significant increase amounted by 0.11 and 0.42 ton /fed. compared with $60 \%$ and $100 \%$ water stress levels. Despite greater sugar content under severe drought (60\% of IWR), the root yield of sugar beet was less than under full irrigation (100\% of IWR). These reductions in root yield could be due to the depressive effect of drought stress on sugar beet growth, in terms of LAI, increasing stomata closure $\%$ and decreasing stomata area which were reflected on the lower RGR and NAR (Table 6, Fig.3 and4). The reason of increasing sucrose \% by moderate and severe drought stress might be due to the fact that under drought, cell size was lower since the cells were not expanded to normal size. All factors which inhibit cell expansion and thereby, the distance between the cambium rings shorten the diffusion pathway from the phloem to the vacuole of single cells, increase the concentration gradient and thereby sucrose transport into the cell. It also decreasing root water content led to increasing sucrose concentration in root cells (Bell et al., 1996). This may explain why at a given distance between rings, the sucrose concentration was higher under drought than under sufficient water supply. These results are in harmony with those reported by Abd El-All and Makhlouf (2017) who stated that, irrigating sugar beet with $100 \% \mathrm{ET}_{\mathrm{c}}$ obtained the higher root and sugar yields, while, $75 \% \mathrm{ET}_{\mathrm{c}}$ obtained the higher sugar quality under drip irrigation in sandy soil. El-Sayed et al. (2018) found that juice quality of sugar beet (sucrose and purity) significantly increased as water stress increased while juice impurities decreased. Increasing water stress level significantly decreased root and sugar yields of sugar beet (Emara and Hamed, 2019). ElKady et al. (2019) found that root and sugar yield/fed were significantly increased by 
increasing IWR from 60 to $100 \%$.

\subsection{Effect of mulch types}

\subsubsection{Growth traits}

Significant effect of mulch types was observed on crop growth rate (CGR), relative growth rate (RGR), net assimilation rate (NAR) and leaf area index (LAI) of sugar beet in both seasons (Table 6). All mulch types significantly increased growth traits compared to non-mulch. Black polyethylene film mulch (BPFM) at stage 105-135 DAP showed superior performance in all growth attributes. Meanwhile, straw mulch was in the second rank, followed by sawdust mulch. These results might be due to the fact that sugar beet plant covered by polyethylene film mulch (BPFM) with 50 microns thickness was more efficient on water saving by reducing the evaporation of the water from the soil more than other mulch types and recorded the lower stomata closure $\%$ and higher size and led to increasing intercellular $\mathrm{CO}_{2}$ concentrations and assimilation which in turn improved the total amount of dry matter accumulated in the plant during growth as shown in Fig. (3 and 4). Also, most mulch in common usage is some types of organic material increased the humus content of soil where they undergo decomposition, activation soil microorganisms which improved growth traits (Hassan, 1999). Similar trend was reported by Sanbagavalli et al. (2017) who stated that the straw mulch recorded high crop growth rate (CGR) of soybean (12.40 $\mathrm{g} / \mathrm{m}^{2} /$ day) at 30-45 days after planting.

\subsubsection{Photosynthetic pigments, proline and leaf relative water content}

Table (7) indicates that leaf chlorophyll a and $b$, carotenoids, proline concentration and leaf relative water content (LRWC) were significantly affected by all types of mulching in both seasons except proline concentration in the $1^{\text {st }}$ season, the maximum pigments (chlorophyll a, b) and LRWC\% were observed under the BPFM mulch followed by straw mulch, while the minimum values were observed under sawdust mulch. In contrast, the highest carotenoids content was provided by straw mulch in both seasons. All mulching types significantly increased the last mentioned traits compared to non-mulch in both seasons. The increase in leaf pigments of mulched plants was possibly due to lower stomata closure \% with improving intercellular $\mathrm{CO}_{2}$ concentrations, especially with BPFM mulch as shown in (Fig. 4), In addition better availability of soil moisture and optimum soil temperature provided by the mulches and availability of uptake of nutrients. Regarding proline concentration, the obtained results proved that proline accumulation was lower in mulched plants with BPFM followed by rice straw. All mulching types recorded the minimum proline accumulation compared with nonmulch in both seasons which might be due to the influence effect of different mulch types on decreasing the hazard effect created by water stress. The same trend was observed by Zhang et al. (2015) who reported that the highest chlorophyll content of maize was recorded by straw mulching compared with no mulch. Xue et al., (2016) showed that inorganic and organic mulch increased chlorophyll a by $36.3 \%$ compared with un-mulching and did not affect proline accumulation of tea olive.

\subsubsection{Yield and quality}

Data presented in Table (8) showed that all mulching types significantly affected the root and sugar yields and quality traits, i.e. sucrose $\%$, extractable sugar $\%$, purity $\%$ and impurities $\%$ in both seasons except sugar yield in the $2^{\text {nd }}$ season. Polyethylene plastic film mulch (BPFM) produced $42.36 \%$ and $40.72 \%$ higher root yield in the $1^{s t}$ and the $2^{\text {nd }}$ seasons respectively, and $6.65 \%$ higher purity $\%$ in the $2^{\text {nd }}$ season and finally $14.19 \%$ higher sugar yield in the $1^{\text {st }}$ season compared to the control (non- mulch). In the same time, non-mulch treatment recorded the highest sugar content (20.55 and 21.70 $\%$ ), extractable sugar \% (18.49 and 19.38\%) in the $1^{s t}$ and $2^{n d}$ seasons, respectively as well as purity \% $(85.88 \%)$ in the $1^{\text {st }}$ season. On the other hand, the non-mulch treatment recoded the minimum sugar beet root yield (16.43 and17.24 ton $\left.\mathrm{fed}^{-1}\right)$ in the $1^{\text {st }}$ and the $2^{\text {nd }}$ seasons, respectively, and sugar yield (3.03 ton $\left.\mathrm{fed}^{-1}\right)$ in the $1^{\text {st }}$ season followed by sawdust mulch which recoded (19.83 and 18.48 ton fed $^{-1}$ ) root yield in the $1^{s t}$ and the $2^{\text {nd }}$ seasons, respectively.. The same trend was observed by (Hatamian and Salehi, 2017and Artyszak et al., 2014) they reported higher sugar yield when the sugar beet crop was sown in mulched condition in comparison to no mulching. Malik et al. 


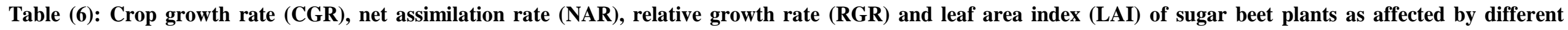
irrigation levels and mulch types during $2017 / 2018$ and $2018 / 2019$ seasons.

\begin{tabular}{|c|c|c|c|c|c|c|c|c|c|c|c|c|c|c|}
\hline \multirow{3}{*}{$\begin{array}{l}\text { Characteristics } \\
\text { Seasons } \\
\text { Periods (DAP*) }\end{array}$} & \multicolumn{4}{|c|}{ CGR* (g/week) } & \multicolumn{4}{|c|}{ NAR* $\left(\mathrm{g} / \mathrm{cm}^{2} /\right.$ week $)$} & \multicolumn{4}{|c|}{ RGR* (g/g/week) } & \multicolumn{2}{|c|}{ LAI* } \\
\hline & \multicolumn{2}{|c|}{$2017 / 18$} & \multicolumn{2}{|c|}{$2018 / 19$} & \multicolumn{2}{|c|}{$2017 / 18$} & \multicolumn{2}{|c|}{$2018 / 19$} & \multicolumn{2}{|c|}{$2017 / 18$} & \multicolumn{2}{|c|}{$2018 / 19$} & \multirow[t]{2}{*}{$2017 / 18$} & \multirow[t]{2}{*}{$2018 / 19$} \\
\hline & $\mathbf{1 0 5 - 1 3 5}$ & $135-165$ & $105-135$ & $135-165$ & 105-135 & 135-165 & $\mathbf{1 0 5 - 1 3 5}$ & 135-165 & $105-135$ & 135-165 & 105-135 & $135-165$ & & \\
\hline Treatments & \multicolumn{14}{|c|}{ Irrigation levels } \\
\hline $100 \%$ of IWR* & 13.12 & 12.31 & 13.58 & 12.46 & 3.09 & 2.57 & 3.14 & 2.64 & 0.083 & 0.056 & 0.092 & 0.064 & 3.69 & 4.52 \\
\hline $80 \%$ of IWR & 13.08 & 12.22 & 13.12 & 11.96 & 3.12 & 2.60 & 3.13 & 2.65 & 0.085 & 0.058 & 0.098 & 0.069 & 3.83 & 4.55 \\
\hline $60 \%$ of IWR & 12.32 & 11.94 & 12.48 & 11.37 & 2.83 & 2.21 & 2.77 & 2.18 & 0.072 & 0.050 & 0.070 & 0.058 & 2.93 & 3.98 \\
\hline LSD at $5 \%$ & 0.03 & 0.04 & 0.03 & 0.01 & 0.01 & 0.01 & 0.02 & 0.05 & 0.004 & NS* & 0.002 & NS & 0.03 & 0.04 \\
\hline \multicolumn{15}{|c|}{ Mulching types } \\
\hline No-mulching & 12.23 & 11.88 & 12.42 & 10.94 & 2.72 & 2.19 & 2.61 & 2.13 & 0.071 & 0.048 & 0.076 & 0.056 & 3.29 & 4.15 \\
\hline BPFM* & 13.44 & 12.34 & 14.00 & 12.91 & 3.21 & 2.70 & 3.29 & 2.78 & 0.087 & 0.061 & 0.097 & 0.071 & 3.88 & 4.59 \\
\hline Sawdust & 12.58 & 12.26 & 12.60 & 11.56 & 3.00 & 2.35 & 3.02 & 2.43 & 0.079 & 0.056 & 0.085 & 0.061 & 3.26 & 4.25 \\
\hline Paddy straw & 13.12 & 12.14 & 13.21 & 12.31 & 3.12 & 2.59 & 3.14 & 2.62 & 0.084 & 0.053 & 0.090 & 0.067 & 3.50 & 4.41 \\
\hline LSD at 5\% & 0.02 & 0.03 & 0.02 & 0.01 & 0.02 & 0.01 & 0.01 & 0.02 & 0.002 & 0.001 & 0.001 & 0.001 & 0.01 & 0.04 \\
\hline Interaction & NS & NS & NS & NS & 0.03 & 0.02 & 0.02 & 0.04 & NS & NS & NS & NS & 0.02 & 0.06 \\
\hline $\begin{array}{l}\text { CGR }=\text { crop g } \\
\text { IWR }=\text { irrigati }\end{array}$ & require & & & $\begin{array}{l}\mathrm{R}=\text { net assi } \\
\mathrm{M}=\text { black }\end{array}$ & $\begin{array}{l}\text { ilation rate } \\
\text { lyethylene }\end{array}$ & film mulch & & $\begin{array}{l}\mathrm{GR}=\text { relati } \\
\mathrm{NS}=\text { non }-\mathrm{s}\end{array}$ & $\begin{array}{l}\text { growth } \\
\text { ificant }\end{array}$ & & $\begin{array}{l}=\text { leaf ar } \\
=\text { days }\end{array}$ & $\begin{array}{l}\text { lex } \\
\text { planting }\end{array}$ & & \\
\hline
\end{tabular}

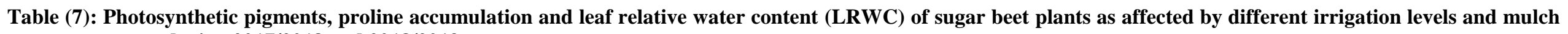
types during 2017/2018 and 2018/2019 seasons.

\begin{tabular}{|c|c|c|c|c|c|c|c|c|c|c|}
\hline \multirow{3}{*}{$\begin{array}{c}\text { Characteristics } \\
\text { Seasons }\end{array}$} & \multicolumn{6}{|c|}{ Photosynthetic pigments (mg/g f.w.) } & \multirow{2}{*}{\multicolumn{2}{|c|}{$\begin{array}{c}\text { proline accumulation } \\
\text { (u moles/g leaf fresh weight) }\end{array}$}} & \multirow{2}{*}{\multicolumn{2}{|c|}{ LRWC* $(\%)$}} \\
\hline & \multicolumn{2}{|c|}{ Chl. $\mathbf{a}^{*}$} & \multicolumn{2}{|c|}{ Chl. b* } & \multicolumn{2}{|c|}{ Carot.* } & & & & \\
\hline & $2017 / 18$ & $2018 / 19$ & $2017 / 18$ & $2018 / 19$ & $2017 / 18$ & $2018 / 19$ & $2017 / 18$ & $2018 / 19$ & $2017 / 18$ & $2018 / 19$ \\
\hline Treatments & \multicolumn{10}{|c|}{ Irrigation levels } \\
\hline $100 \%$ of IWR* & 4.18 & 4.29 & 2.33 & 2.30 & 0.850 & 1.101 & 3.15 & 3.00 & 86.31 & 89.14 \\
\hline $80 \%$ of IWR & 4.21 & 4.24 & 2.32 & 2.37 & 0.827 & 1.079 & 2.97 & 3.25 & 84.54 & 87.01 \\
\hline $60 \%$ of IWR & 3.86 & 3.98 & 1.78 & 1.83 & 0.815 & 0.797 & 4.00 & 3.74 & 76.21 & 78.00 \\
\hline \multirow[t]{2}{*}{ LSD at $5 \%$} & 0.04 & $\mathbf{0 . 0 3}$ & $\mathbf{0 . 0 3}$ & $\mathbf{0 . 0 2}$ & $\mathbf{0 . 0 2}$ & 0.015 & 0.58 & 0.02 & 0.39 & 0.19 \\
\hline & \multicolumn{10}{|c|}{ Mulching types } \\
\hline No-mulching & 3.93 & 3.61 & 1.83 & 1.87 & 0.708 & 0.798 & 3.57 & 3.45 & 76.71 & 78.50 \\
\hline BPFM* & 4.21 & 4.43 & 2.29 & 2.33 & 0.921 & 1.103 & 3.33 & 3.23 & 85.93 & 88.61 \\
\hline Sawdust & 4.04 & 4.27 & 2.15 & 2.20 & 0.829 & 0.997 & 3.50 & 3.34 & 82.47 & 84.70 \\
\hline Paddy straw & 4.14 & 4.37 & 2.27 & 2.30 & 0.866 & 1.071 & 3.09 & 3.30 & 84.30 & 87.07 \\
\hline LSD at $5 \%$ & 0.02 & 0.01 & 0.02 & 0.01 & 0.017 & 0.022 & NS* & 0.02 & 0.53 & 0.34 \\
\hline Interaction & 0.04 & 0.02 & $\mathbf{0 . 0 3}$ & 0.02 & NS & NS & NS & $\mathbf{0 . 0 3}$ & 0.91 & $\mathbf{0 . 5 8}$ \\
\hline \multicolumn{3}{|l|}{$\begin{array}{l}\text { Chl.a = chlorophyll a } \\
\text { BPFM= black polyethyl }\end{array}$} & $\begin{array}{l}\text { Chl.b }= \\
\mathrm{NS}=\mathrm{nc}\end{array}$ & $\begin{array}{l}\text { ophyll b } \\
\text { gnificant }\end{array}$ & \multicolumn{6}{|c|}{$\begin{array}{l}\text { Carot. }=\text { Carotene } \\
\text { LRWC }=\text { leaf relati }\end{array}$} \\
\hline
\end{tabular}


Table (8): Root and sugar yields and quality traits of sugar beet as affected by different irrigation levels and mulch types during 2017/2018 and 2018/2019 seasons.

\begin{tabular}{|c|c|c|c|c|c|c|c|c|c|c|c|c|}
\hline \multirow{3}{*}{$\begin{array}{c}\text { Characteristics } \\
\text { Seasons }\end{array}$} & \multirow{2}{*}{\multicolumn{2}{|c|}{ Root yield (ton/fed) }} & \multirow{2}{*}{\multicolumn{2}{|c|}{ Sugar yield (ton/fed) }} & \multicolumn{8}{|c|}{ Quality parameters } \\
\hline & & & & & \multicolumn{2}{|c|}{ Sucrose $\%$} & \multicolumn{2}{|c|}{ Extractable sugar\% } & \multicolumn{2}{|c|}{ Purity\% } & \multicolumn{2}{|c|}{ Impurities $\%$} \\
\hline & $2017 / 18$ & 2018/19 & 2017/18 & 2018/19 & 2017/18 & 2018/19 & $2017 / 18$ & 2018/19 & 2017/18 & 2018/19 & $2017 / 18$ & 2018/19 \\
\hline Treatments & \multicolumn{12}{|c|}{ Irrigation levels } \\
\hline $100 \%$ of IWR* & 20.78 & 22.64 & 3.06 & 3.15 & 17.87 & 17.79 & 14.95 & 14.23 & 81.85 & 84.00 & 2.92 & 3.56 \\
\hline $80 \%$ of IWR & 20.76 & 19.89 & 3.48 & 3.25 & 19.26 & 19.33 & 16.91 & 16.59 & 82.83 & 81.90 & 2.35 & 2.74 \\
\hline $60 \%$ of IWR & 18.44 & 18.63 & 3.37 & 3.70 & 20.31 & 22.29 & 18.38 & 20.10 & 84.41 & 80.44 & 1.93 & 2.20 \\
\hline LSD at $5 \%$ & 1.34 & 1.08 & 0.28 & 0.17 & 0.72 & 0.80 & 0.70 & 0.71 & 1.30 & 2.38 & 0.16 & 0.16 \\
\hline \multicolumn{13}{|c|}{ Mulching types } \\
\hline No-mulching & 16.43 & 17.24 & 3.03 & 3.32 & 20.55 & 21.70 & 18.49 & 19.38 & 85.88 & 79.89 & 2.06 & 2.32 \\
\hline BPFM* & 23.39 & 24.26 & 3.46 & 3.45 & 17.47 & 17.50 & 14.73 & 14.48 & 81.40 & 85.20 & 2.74 & 3.03 \\
\hline Sawdust & 19.83 & 18.48 & 3.28 & 3.33 & 19.03 & 21.01 & 16.57 & 18.23 & 81.95 & 81.50 & 2.46 & 2.79 \\
\hline Paddy straw & 20.32 & 21.57 & 3.44 & 3.38 & 19.53 & 19.00 & 17.20 & 15.80 & 82.89 & 81.84 & 2.34 & 3.20 \\
\hline LSD at $5 \%$ & 0.83 & 1.27 & 0.24 & NS & 0.90 & 1.00 & 0.87 & 1.03 & 1.31 & 1.89 & 0.21 & 0.19 \\
\hline Interaction & 1.43 & NS & 0.14 & NS & NS & NS & NS & NS & NS & NS & NS & 0.32 \\
\hline
\end{tabular}

IWR= irrigation water requirements

BPFM= black polyethylene film mulch 
(2018) reported that the use of black polyethylene film mulch was found better compared to straw mulch, and increased root yield of sugar beet by 11.96 to $19.45 \%$ over non-mulch.

\subsection{Interaction effects}

Results of the interaction between water stress levels and mulching types (Figs. 1 and 2) showed that root yield and LAI in the $1^{s t}$ season as well as chlorophyll a and impurities $\%$ in the $2^{\text {nd }}$ season under Black polyethylene film mulch (BPFM) $+100 \%$ IWR were observed to be significantly higher than other treatments, while BPFM + $80 \%$ of IWR recorded significantly high NAR and chlorophyll $b$ in the two seasons and sugar yield and chlorophyll a in the $1^{\text {st }}$ season. On the other hand, the minimum values of the previous traits were associated with no mulch $+60 \%$ of IWR in both seasons. Concerning proline concentration, no mulch $+60 \%$ of IWR gave the maximum values of proline in the $2^{\text {nd }}$ season, meantime the lowest proline contents were recorded by straw mulch $+100 \%$ of IWR. Similarly, Karam (2016) reported that, the highest vegetative and yield of potato were obtained by polyethylene black mulch treatment combined with $100 \%$ irrigation requirements.

\subsection{Analysis of stoma to morphological parameters}

In relation to the morphological changes of stomata response to water stress levels and mulch types, the microscopic analysis (images a, b, c, and d) showed that water

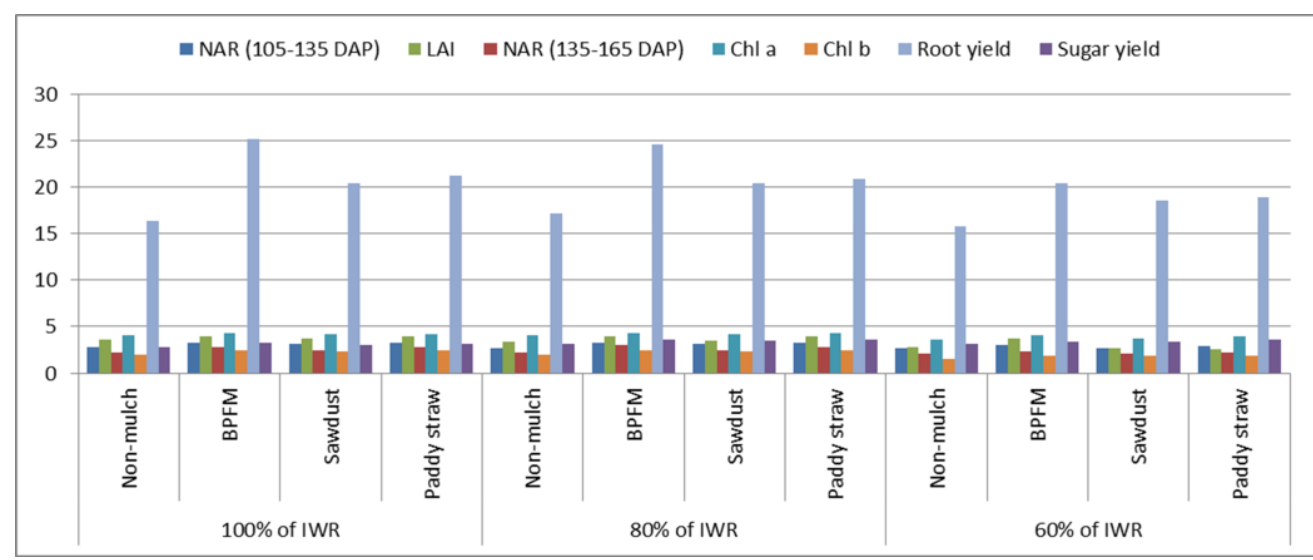

Fig. (1): Net assimilation rate (NAR) $\left(\mathrm{g} / \mathrm{cm}^{2} /\right.$ week), leaf area index (LAI), chlorophyll a and b (mg/g f.w.), root yield (ton fed ${ }^{-1}$ ) and sugar yield (ton fed ${ }^{-1}$ ) of sugar beet plants as affected by significant interaction between different irrigation levels and mulch types during 2017/2018 season.

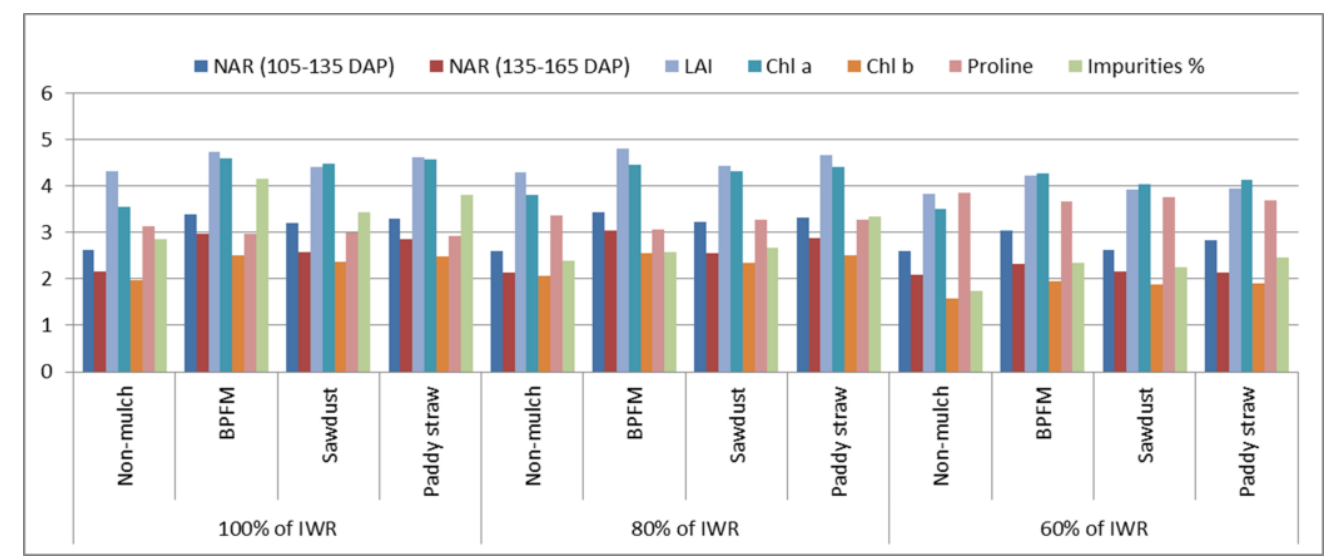

Fig. (2): Net assimilation rate (NAR) $\left(\mathrm{g} / \mathrm{cm}^{2} /\right.$ week), leaf area index (LAI), chlorophyll a and $\mathrm{b}$ ( $\mathrm{mg} / \mathrm{g}$ f.w.), proline (u moles/g) and impurities \% of sugar beet plants as affected by significant interaction between different irrigation levels and mulch types during 2018/2019 season. 
deficit and mulch types affected stomata density, size, stomata closure $\%$ and its index \% (the percentage of stomata number to the total cell number on a given leaf area). Individual response to increased waterdeficient and different mulch types was observed for each parameter of stomata. A negative relationship between stomata density and size or area was found by (Doheny et al., 2012). The distribution of stomata density between both lower surface (abaxial) and upper surface (adaxial) of the leaves was increased in a much more pronounced way for the abaxial than the adaxial leaf surface as water stress levels increased (Fig. 3). Another different behavior for stomata closure \% was found
(Fig. 4) with decreasing the amount of irrigation water from $100 \%$ to $80 \%$ and $60 \%$ of IWR, there were slight differences between full irrigation (100\%) and moderate stress ( $80 \%$ of IWR) but stomata were closed under severe stress (60\% of IWR) as a result of loss of guard cell turgor pressure. All mulching types under different water stress level had positive effects and increased stomata area but decreased stomata density and its index as well as stomata closure percentage compared with non-mulch (Figs. 3 and 4). The microscopic analysis (Image a, b, c, and d) showed that: the higher stomata area, lower stomata density (Fig. 3) and stomata closure \% (Fig. 4) were recorded by black polyethylene film

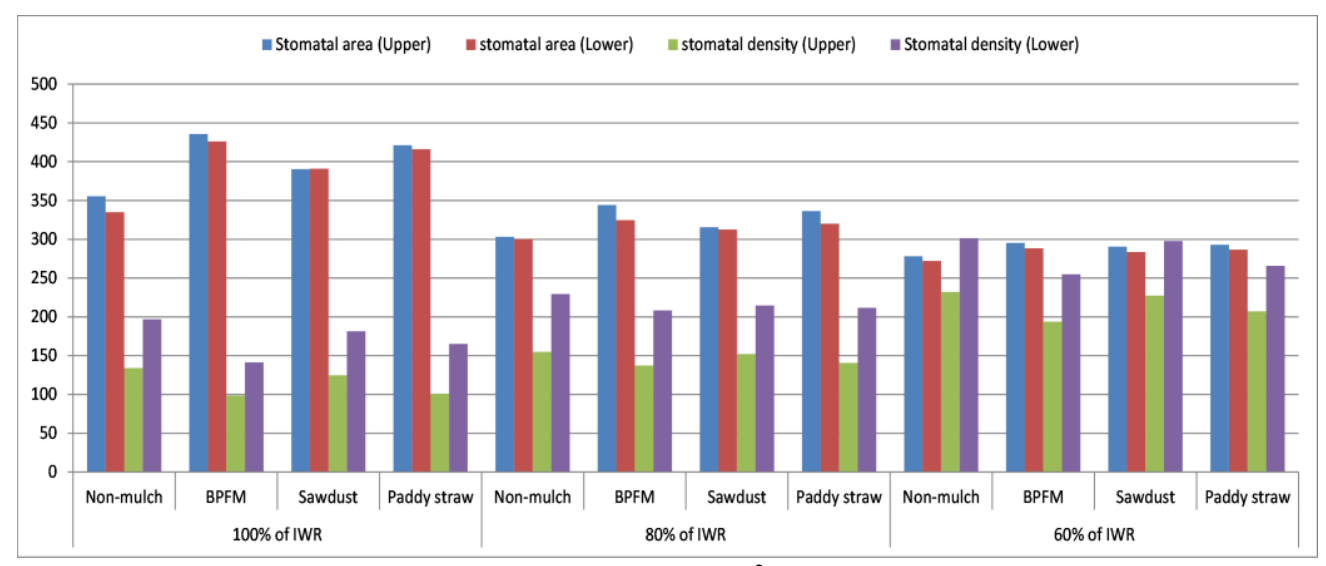

Fig. (3): Stomatal area $(\mu \mathrm{m})$ and density $\left(\mathrm{No} . \mathrm{mm}^{-2}\right)$ for upper and lower surfaces of sugar beet leaf as affected by different irrigation levels and mulch types (average of two seasons).

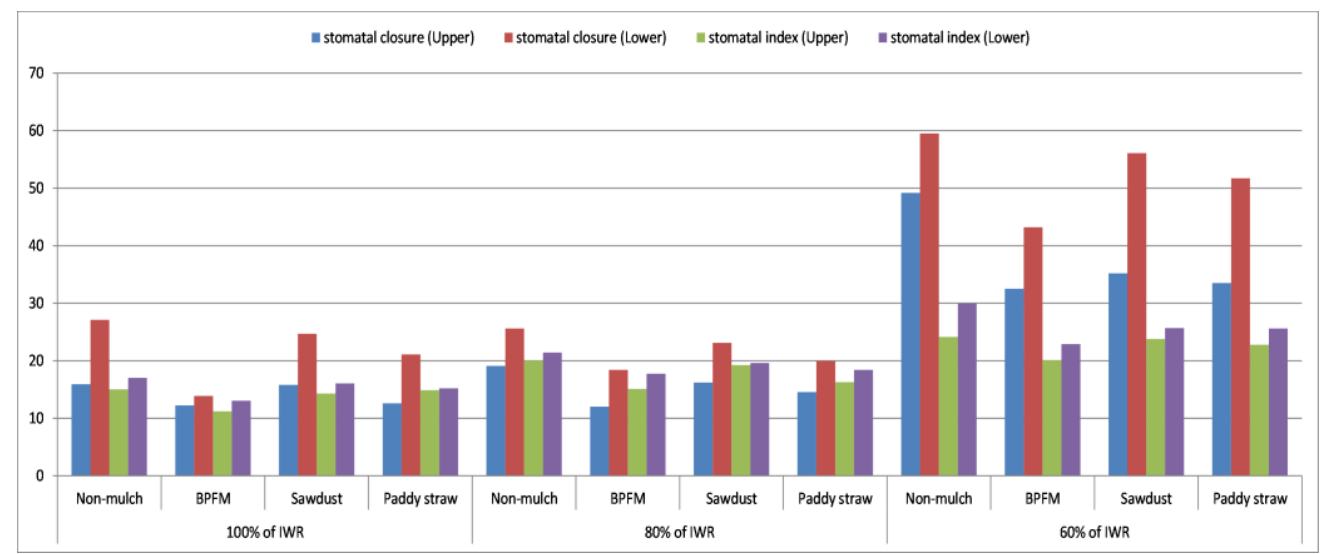

Fig. (4): Stomatal closure\% and stomata index (SI \%) for upper and lower surfaces of sugar beet leaf as affected by different irrigation levels and mulch types (average of two seasons). 

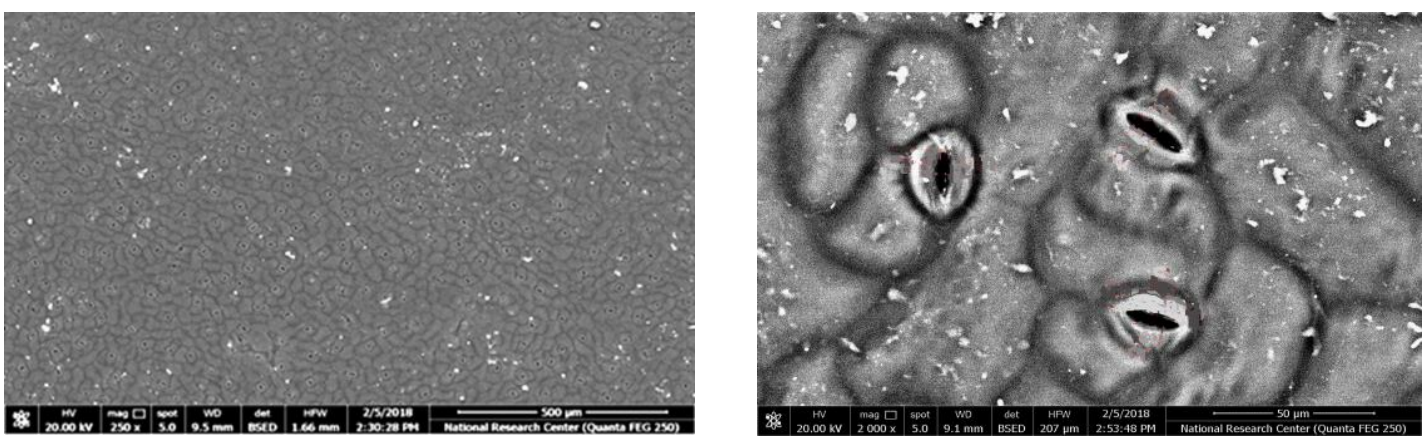

Image a: Electron microscopic images (magnification $250 \mathrm{x}$ and $2000 \mathrm{x}$ ) of (upper) adaxial surface stomata of sugar beet leaf under black polyethylene film mulch (BPFM) with $100 \%$ of IWR.
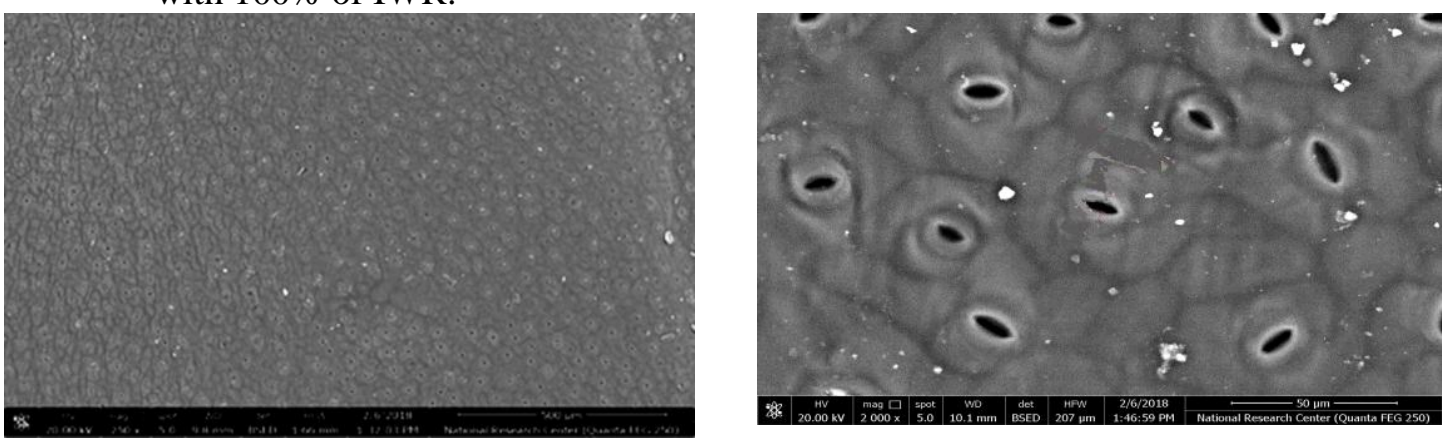

Image b: Electron microscopic images (magnification.250 $\mathrm{x}$ and $2000 \mathrm{x}$ ) of (Lower) abaxial surface stomata of sugar beet leaf under black polyethylene film mulch (BPFM) with $100 \%$ of IWR.
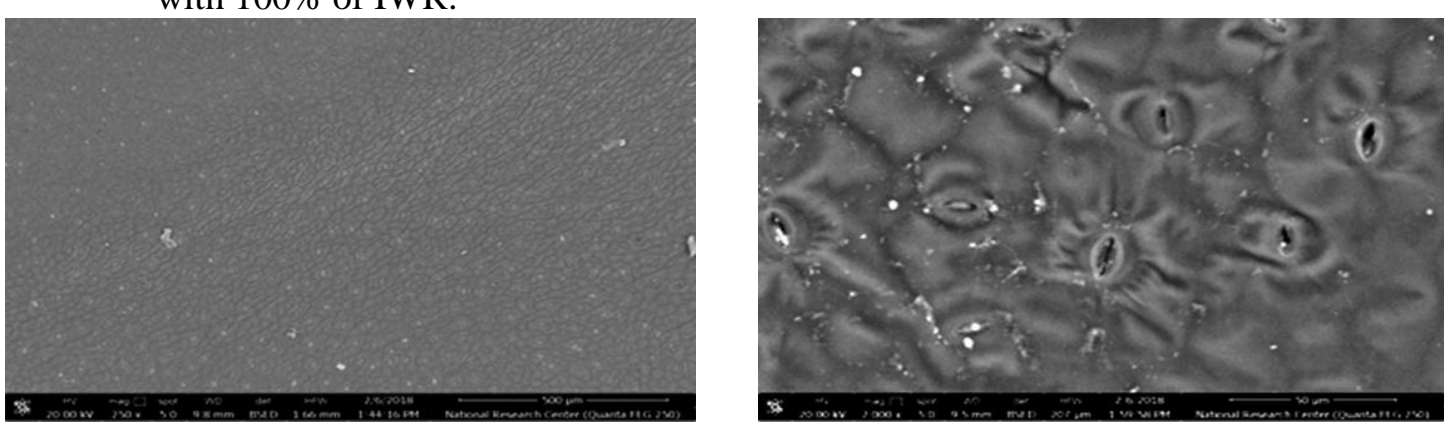

Image c: Electron microscopic images (magnification $250 \mathrm{x}$ and $2000 \mathrm{x}$ ) of (upper) adaxial surface stomata of sugar beet leaf under $60 \%$ of IWR (severe treatment) with nonmulch.
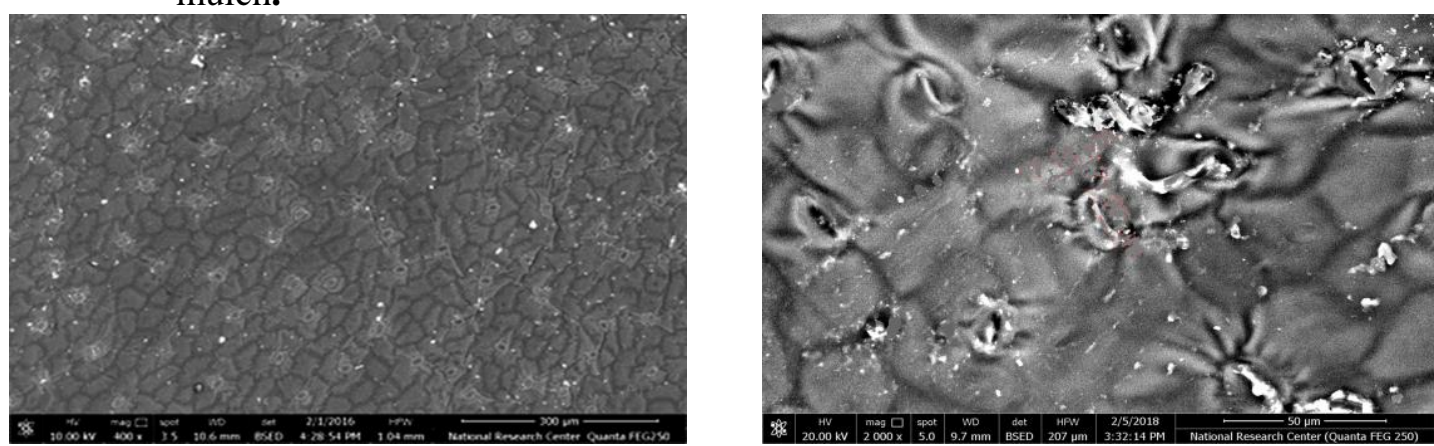

Image d: Electron microscopic images (magnification $250 \mathrm{x}$ and $2000 \mathrm{x}$ ) of (lower) abaxial surface stomata of sugar beet leaf under $60 \%$ of IWR (severe treatment) with nonmulch. 
mulch (BPFM) with $100 \%$ of IWR (Images $\mathrm{a}$ and $\mathrm{b}$ ). Water deficit at $60 \%$ of IWR (severe treatment) with non-mulch affected all stomata parameter and recorded the highest stomata closure \%, an increase in density and reduce dimensions (Images $\mathrm{c}$ and d). Franks et al. (2009) suggested that taking into account the leaf area limitation, there is a point when the only way to increase stomata conductance is by decreasing stomata size and increasing density. Many researchers indicated that drought stress results in increasing stomata density; McCree and Davis (1974) in sorghum; Zhang et al. (2006) in wheat; and a decrease in stomata size. Spence et al. (1986) reported that high density and small size of stomata may enhance adaptation of plant to drought; it allows plants to be more efficient in regulation of water transport and transpiration (Dickison, 2000).

\section{Conclusions}

Evaluating sugar beet crop under dry climatic conditions in sandy soil, revealed that most of physiological and yield characteristics significantly increased by increased irrigation levels from $60 \%$ up to 80 and $100 \%$ of irrigation water requirements (IWR) in both seasons. Vice versa, proline and quality parameters of sugar beet plants decreased by increase irrigation levels from $60 \%$ to $100 \%$ of IWR. On the other hand, covering soil by inorganic mulch [black polyethylene film mulch (BPFM)] was significantly more efficient on the physiological and yield parameters followed by organic cover (paddy straw and sawdust) compared to non-mulching in the two seasons. Finally, the highest sugar yield (ton $\mathrm{fed}^{-1}$ ) was observed under $80 \%$ (moderate stress) of IWR and covering soil by black polyethylene film mulch (BPFM) under drip irrigation system.

\section{REFERENCES}

Abd El-All A. E. A. and Makhlouf B.S.I. (2017). Response of sugar beet to continuous deficit irrigation and foliar application of some micronutrients under sandy soil conditions. J. Soil Sci. Agric. Eng., Mansoura Univ., 8(12): 749-760.

Amr M. A., Mohsen A. G., Mahmoed A. S. and Mohamed Z.K. (2017). Water stress effects on yield and Quality of sugar beet crop in sandy soils. Alex. Sci. Exchange J., 38(4):828-836

AQUASTAT, FAO (Food and Agriculture Organization of the United Nations) (2016). global water info. System Land Water Div., Rome.Italy.

Arora V.K., Singh C.B., Sidhu A.S. and Thind S.S. (2011). Irrigation, tillage and mulching effects on soybean yield and water productivity in relation to soil texture. Agric. Water Manage., 98: 563-568.

Artyszak A., Gozdowski D. and Kucińska K. (2014). The yield and technological quality of sugar beet roots cultivated in mulches. Plant Soil Enviro., 60(10): 464-469.

Azab Enas S. (2018). Seed pre-soaking on gibberellic acid $\left(\mathrm{GA}_{3}\right)$ enhance growth, histological and physiological traits of sugar beet (Beta vulgaris L) under water stress. Egypt. J. Agron., 40(2): 119-132.

Bates L.S., Waldran R.P. and Teare I.D. (1973). Rapid determination of free proline for water studies. Plant Soil, 39: $205-208$.

Bell C.I., Milford G.F.J. and Leigh R.A. (1996). Sugar beet. In: E. Zamski, and A.A. Schaffer, (eds). Photo assimilate Distribution in Plants and Crops: Source-Sink Relationships. Books in Soils, Plants, and the Environment 48, pp. 691-707. Marcel Dekker Inc., New York., USA.

Balak DGR. (1993). A growth analysis comparison of corn growth in conventional and equidistant plant spac-ing. Crop Sci., 24:1184-1191.

Blaney H.F. and Criddle W.D. (1962). Determining consumptive use and irrigation water requirements, USDA tech., bull., 1275. US Depart. Agric., Beltsville., yD.USA.

Carruthers A. and Oldfield J.ET. (1960). Methods for the assessment of beet quality. Int'l. Sugar J., 63(1): 103-105.

Chapman H.D. and Praft P.F. (1961) Methods of analysis for soils, plants and waters. University of California, Los Angeles, 60-61, 150-179.

Chaves M. M., Pereira J. S., Maroco J., 
Rodrigues M.L., Ricardo C.P.P., Osorio M.L., Carvalho I., Faria T. and Pinheiro C. (2002). How plants cope with water stress in the field. Photosynthesis and growth. Annals Bot. 89: 907-916.

Chaves M.M, Maroco J.P. and Pereira J.S. (2003). Understanding plant responses to drought-from genes to the whole plant. Funct. Plant Biol., 30: 239-264

Cooke D.A. and Scott R. K. (1993). The sugar beet crop. Chapman and Hall London, U.K. pp.262-265.

Cottenie A., Verloo M., Velghe G. and Cameriynck R. (1982). Chemical analysis of plant and soil. Lab. Analytical Agrochemistry, State Univ., Ghent, Belgium.

Dickison W.C. (2000). Integrative plant anatomy.: Academic Press, San Diego, USA.

Doheny-Adams T., Hunt L., Franks P.J., Beerling D.J. and Gray J.E. (2012). Genetic manipulation of stomatal density influences stomatal size, plant growth and tolerance to restricted water supply across a growth carbon dioxide gradient. Philos. Trans. R. Soc. Lond. Ser. B Biol. Sci. 367, 547-555. doi: 10.1098/rstb.2011.0272

Doorenbos J. and Kassam A.H. (1979).Yield response to water. FAO irrigation and drainage paper No. 33, Rome, Italy.

El-Kady M.S., Ali A.M.K. and Galal M.O.A. (2019). Growth, yield, water use efficiency and agro-economic return of sugar beet as affected by irrigation systems, water and nitrogen stresses in Moghra region, Matrouh, Egypt. J. Biol. Chem. Environ. Sci., 14 (2): 265-287.

El-Sayed A. M., Mahmoud A. Hassanina, Taha I. Borhamb, and Emara E. I.R. (2018). Tolerance of some sugar beet varieties to water stress. Agric. Water Manage., 201: 144-151.

Emara E. I.R. and Hamed L. M.M. (2019). Response of some sugar beet varieties to water stress. Geophysic. Res. Abst. 2: p.1231.

FAO (1979). Food and agricultural organization of the United Nations. food outlook, Rome, Italy.

Franks P.J., Drake P.L. and Beerling D.J. (2009). Plasticity in maximum stomatal conductance constrained by negative correlation between stomatal size and density: an analysis using Eucalyptus globules, Plant Cell Environ., 32:17371748.

Gong H.J., Zhu X.Y., Chen K.M., Wang S.M. and Zhang C.L. (2005). Silicon alleviates oxidative damage of wheat plants in pots under drought. Plant Sci., 169: 313-321.

Hassan M.J. (1999). Effect of soil moisture management and nitrogen levels on growth and yield of garlic. M.S.c Thesis, Department of Horticulture Bangladesh Agric. Univ., Mymensingh, PP. 49-52.

Hatamian M. and Salehi H. (2017). Physiological characteristics of two rose cultivars (Rosa hybrid L.) under different levels of shading in greenhouse conditions. J. Ornament. Plants. 7(3):147-155.

Jalota S.K. and Prihar S.S. (1998). Reducing soil water evaporation with tillage and mulching. Iowa State Univ. Press, Ames. IA. USA. 142P.

Kader M.A., Senge M., Mojid M.A. and Ito K. (2017). Recent advances in mulching materials and methods for modifying soil environment. Soil Tillage Res., 168:155-166.

Karam F. (2016). Growth and productivity of potato under different irrigation levels and mulch types in the north west of the Nile delta, Egypt. Middle East J. App. Sci., 6:774-786.

Malik A., Shakir A. S., Khan M. J., Latif N. M., Ajmal M. and Ahmad S. (2018). Effects of different mulching techniques on sugar beet performance under semi-arid subtropical climatic condition. Pak J. Bot., 50(3): 12191224.

Malik A. (2017). Understanding the interaction of deficit irrigation and mulching in raised-bed irrigation system for efficient water use. Ph.D. Thesis, Fac. Civil Eng., Univ. Eng. Tech., Lahore, Pakistan.

Masri M. I., Ramadan B. S. B., El-Shafai A.M.A. and El-Kady M.S. (2015). Effect of water stress and fertilization on yield and quality of sugar beet under drip and sprinkler irrigation systems in sandy soil. Int'l. J. Agric. Sci., 5 (3): 
414-425.

McCree K.J. and Davis S.D. (1974). Effect of water stress and temperature on leaf size and number of epidermal cells in grain sorghum. Crop Sci., 4: 751-755.

Neseim M. R., Amin A. Y. and ElMohammady M. M. S. (2014). Effect of potassium applied with foliar spray of yeast on sugar beet growth and yield under drought stress. Glo. Adv. Res. J. Agric. Sci. 3(8): 211-222.

Özenç D. B. (2008). Growth and transpiration of tomato seedlings grown in Hazelnut Husk compost under waterdeficit stress. Compost Sci. Util., 16: 125-131.

Pidgeon J. D., Ober E.S., Qi A., Clark C.J. A., Royal A. and Jaggard K.W. (2006). Using multi-environment sugar beet variety trials to screen for drought tolerance. Field Crops Res., 95, 268279.

Radfords P.J. (1967). Growth analysis formulae, their use and abuse. Crop Sci., 7: 171-175.

Reinefeld E., Emmerrich A., Baumgarten G., Winner C. and Beiss U. (1974). ZurVaraussage des Melasse Zuchersaus Rbenanalysen. Zucker, 27: 2-25. The Sugar Beet Crop.Cook, D.A. and R.K. Scott Seriess, London, UK.

Sanbagavalli S., Vaiyapuri K. and Marimuthu S. (2017). Impact of mulching and anti-transpirants on growth and yield of soybean (Glycine max L. Merril). Adv. Env. Biol., 11(1), P: 84-89

Saneoka H., Moghaieb R.E.A., Premachandra G.S. and Fujita K. (2004). Nitrogen nutrition and water stress effects on cell membrane stability and leaf water relations in Agrostis palustris Huds. Env. Exp. Bot., 52:131138.
Smith M. (1991). CROPWAT Model for $\mathrm{ET}_{\mathrm{o}}$ Calculation Using PenmanMonteith Equation., FAO Rome, Italy., p. 54.

Snedecor G.W. and Cohran W.G. (1989). Statistical method $6^{\text {th }}$ ed., Iowa State Univ. Press, Ames, Iowa, USA., P. 593.

Spence R.D., Wu H., Sharpe P.J.H., Clark K.G. (1986).Water-stressed effects on guard cell anatomy and the mechanical advantage of the epidermal cells. Plant Cell Env., 9:197-202.

Watson D.J. (1958). The dependence of net assimilation rate on leaf area index. Ann Bot. Lond. N.S., 22: 37-54.

Weatherly P.E. (1950). Studies in the water relations of cotton. 1. The field measurement of water deficits in leaves. New Phytol. 49:81-97.

Wettstein D. (1957). Chlorophy 1l, Letal_und der submikrosvopische formmech, sallplastiden. Expt. Cell Ser., 12: 427-433.

Xue Ni, Weiting S., Huanchao Z., Xiulian Y. and Lianggui W. (2016) Effects of Mulching on Soil Properties and Growth of Tea Olive (Osmanthus fragrans). PLOS ONE 11(8): 1-11.

Zhang X., Qian Y. and Cao C. (2015). Effects of straw mulching on maize photosynthetic characteristics and rhizosphere soil micro-ecological environment. Chilean J. Agric. Res., 75(4): 121-145.

Zhang Y.P., Wang Z.M., Wu Y.C. and Zhang X. (2006). Stomatal characteristics of different green organs in wheat under different irrigation regimes. Acta Agronomica Sinica 32:70-75.

Zribi W., Aragüés R., Medina E. and Faci J.M. (2015). Efficiency of inorganic and organic mulching materials for soil evaporation control. Soil Tillage Resj, 148:40-45. 
M.S. El-Kadv et al., .........................................................................

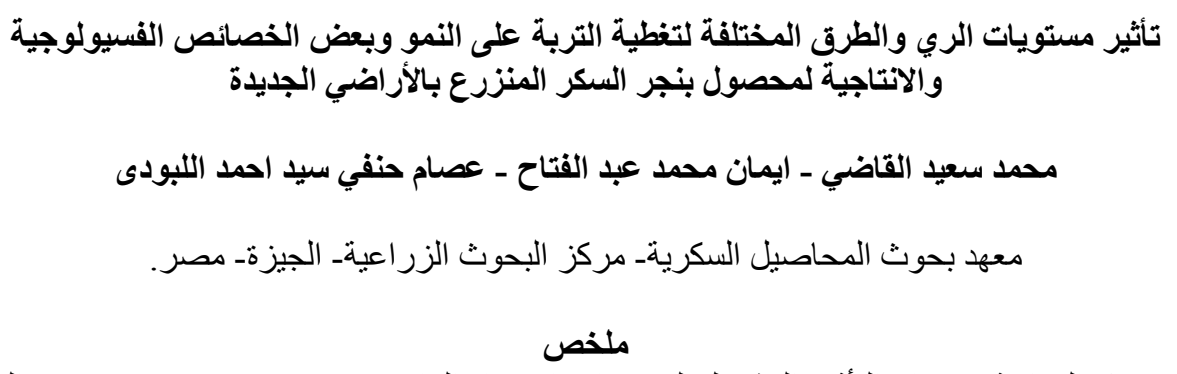

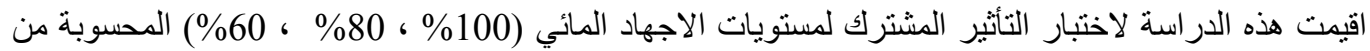

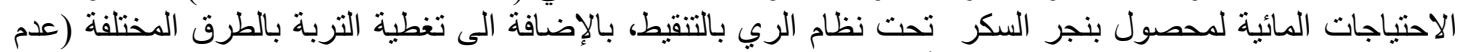

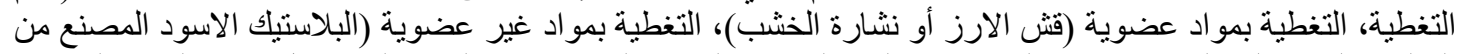

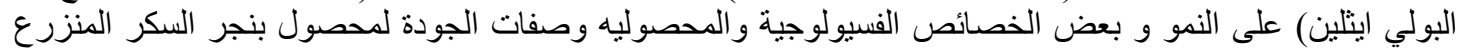

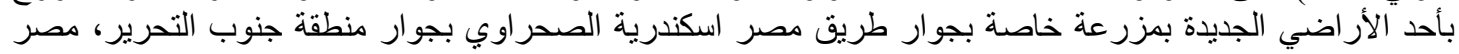
خلال موسمي 2018/2017 و 2019/2018 ـ ـ تم استخدام تصميم القطع المنشقة مرة واحدة في تصميم القطاعات

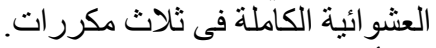

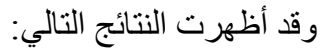

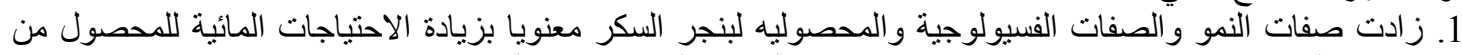

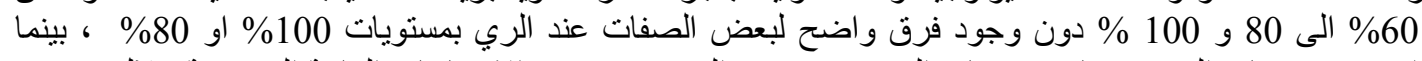
انخفضت صفات الجودة بزيادة مستويات الري من 60 \% \% الى و 100\% من الاحتياجات المائية المحسوبة خلال موسمي الدر اسة.

2. تفوقت معنويا طريقة تغطية التربة بالبلاستيك الاسود المصنع من خامة البولي ايثلين متبو عة بالتغطية بالمو اد العضوية

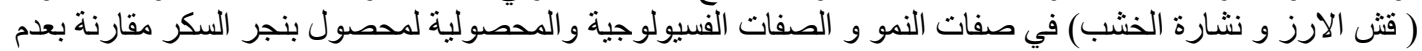

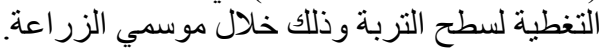

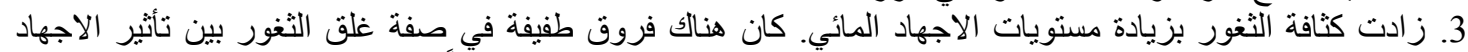
المائي المعتدل ( 80\%) و (60) الري الجيد (100 \%) ولكن هذا الفارق كان و اضحاً وملحوظ تحت نأثنير الاجهاد المائي

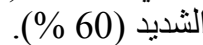

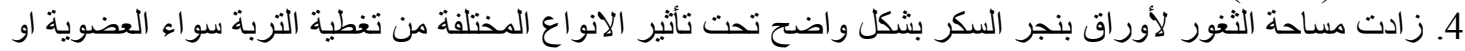

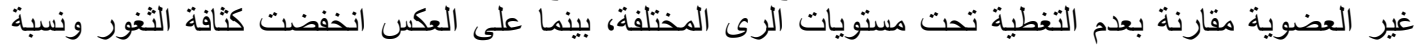
الثغور المغلقة ودليل الثغور. 5. تحقق اعلى محصول سكر ( طن/الفدان) عند الري بمسنوى 80\% من الاحتياجات المائية للمحصول (اجهاد معتدل)

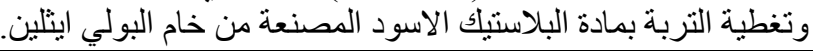

المجلة العلمية لكلية الزراعة - جامعة القاهرة - المجلد (70) العدد الرابع (أكتوبر لئ 2019):408-393. 